\title{
Kombinasi Senam Yoga Dengan Open Kinetik Chain Exercise Menggunakan Music Keroncong Untuk Menurunkan Nyeri Rhematoid Arthritis di Desa Mekar Sari, Narmada Lombok Barat
}

\author{
Istianah $^{1}$, Hapipah ${ }^{2 *}$, Elisa Oktaviana ${ }^{3}$ \\ ${ }^{1,2,3,}$,STIKES YARSI Mataram, Indonesia \\ pey.hapipah15@gmail.com
}

\begin{abstract}
ABSTRAK
Rheumatoid arthritis adalah peradangan sendi akibat sistem kekebalan tubuh yang menyerang jaringannya sendiri. Radang sendi ini menimbulkan keluhan bengkak dan nyeri sendi, serta sendi terasa kaku. Nyeri merupakan masalah utama pada penderita Rematoid Arthritis, sehingga penatalaksanaan penyakit ini berfokus pada upaya mengatasi rasa nyeri. Senam yoga kombinasi open kinetik chain exercise menggunakan music keroncong merupakan salah satu alternatif intervensi untuk menurunkan nyeri Rematoid Arthritis. Tujuan dari pengabdian kepada masyarakat ini untuk meningkatkan pengetahuan warga desa Mekar Sari tentang penyakit Rematoid Arthritis dan dapat menerapkan secara mandiri senam yoga untuk menurunkan rasa nyeri. Pengabdian ini dilakukan di Desa Mekar Sari, dimana didapatkan data sebagian besar warga memiliki keluhan nyeri pada persendian tangan dan kaki, warga tidak mengetahui tentang penyakit Rematoid Arthritis serta tidak mengetahui penatalaksanaan nonfarmakologi untuk menurunkan nyeri yang dirasakan. Metode pengabdian kepada masyarakat ini dilakukan dengan ceramah penyampaian materi, selanjutnya bersama-sama melakukan senam yoga dan evaluasi. Hasil pengabdian menunjukkan setelah diberikan penyuluhan adanya peningkatan pengetahuan tentang Rhematoid Arthritis pada warga Desa Mekar Sari, terjadi penurunan tekanan darah baik sistolik maupun diastolik dan penurunan skala nyeri Rhematoid Arthritis setelah dilakukan senam yoga. Berdasarkan hasil pengabdian diharapkan kegiatan senam yoga ini dapat diterapkan secara mandiri 2 kali seminggu dibalai desa Mekar Sari.
\end{abstract}

Kata Kunci: Senam Yoga, Nyeri, Rematoid Arthritis

Received: October, 29, 2019

Revised: December 20, 2019

Accepted: February 19, 2020

This is an open-acces article distributed under the terms of the Creative Commons Attribution-ShareAlike 4.0 International License.

\section{PENDAHULUAN}

Masa tua merupakan masa yang dimana semua fungsi organ mulai menurun. Berbagai masalah kesehatan atau penyakit mulai muncul termasuk salah satu diantaranya adalah rhematoid arthritis, penyakit ini adalah suatu penyakit autoimun yang di tandai dengan adanya sinovitis erosive simetrik yang mengakibatkan munculnya gejala nyeri dan kaku pada sistem muskuloskleletal. Diperkirakan penderita rhematoid arthritis di dunia 
telah mencapai 335 juta jiwa. Angka ini akan terus meningkat dan pada tahun 2025 diperkirakan lebih dari $25 \%$ akan mengalami kondisi kelumpuhan akibat kerusakan tulang dan penyakit sendi (Andriana, 2016).

Selain rhematoid arthritis penyakit yang umum juga terjadi pada masyarakat lansia adalah gout arthritis, penyakit ini juga dikenal dengan penyakit asam urat yaitu suatu penyakit yang disebabkan oleh undersekresi kristal monosodium urat di dalam darah, akibatnya terjadi penimbunan atau deposit kristal MSU pada jaringan yang akan menyebabkan gout arthritis (Lingga, 2012; Dewi \& Asnita, 2016). Berdasarkan data World Health Organization (WHO, 2017; Dewi \& Asnita, 2016, prevalensi gout arthritis di dunia sebanyak 34,2\%. penyakit gout arthritis tidak hanya terjadi di negara maju saja, tetapi peningkatan juga terjadi di negara berkembang, salah satunya di Negara Indonesia (Kumar dan Lenert, 2016; Dewi \& Asnita, 2016). Prevalensi gout arthritis di Indonesia terus mengalami peningkatan diantaranya pada tahun 2013 kejadian gout arthritis sebesar 11,9\% (Kemenkes RI, 2013; Dewi \& Asnita, 2016).

Rematoid arthtritis dan gout arthritis umumnya sering terjadi pada orang dengan lanjut usia dan di Indonesia jumlah lanjut usia pada tahun 2006 sebanyak 19 juta jiwa, diperkirakan pada tahun 2010 akan mencapai 23,9 juta jiwa, dan perkiraan pada tahun 2020 jumlah lanjut usia akan mencapai 28,8 juta jiwa (Dermawan, 2012 dalam Andriana, 2016). Prevalensi jumlah penduduk lansia khususnya di NTB mencapai 257.589 jiwa (Kemenkes, 2019). Angka kejadian rheumatoid arthritis di Indonesia pada penduduk dewasa (di atas 18 tahun) berkisar $0,1 \%$ hingga $0,3 \%$. sehingga dapat diperkirakan jumlah penderita rheumatoid arthritis di Indonesia mencapai 360.000 orang lebih, yang tersebar di seluruh wilayah kabupaten provinsi di Indonesia. Sedangkan prevalensi gout arthritis di indonesia pada tahun 2013 mencapai 11,9\% (Kemenkes RI, 2013; Dewi \& Asnita, 2016).

Rheumatoid Arthritis adalah penyakit kelainan pada sendi yang menimbulkan nyeri dan kaku pada sistem muskuloskeletal (sendi, tulang, jaringan ikat dan otot). Keluhan yang paling umum di rasakan oleh penderita rematoid artritis dan gout artritis biasanya muncul gejala-gejala keram dan nyeri pada persendian. Setiap individu pernah mengalami nyeri dalam tingkatan tertentu. Nyeri merupakan alasan yang paling umum orang mencari perawatan kesehatan.

Berdasarkan penelitian Zeng QY et al (2008), prevalensi nyeri pada kasus peradangan sendi di Indonesia mencapai 23,6\% hingga 31,3\% (Andriana, 2016). Untuk menghilangkan nyeri biasanya masyarakat sangat bergantung pada obat-obatan. Berdasarkan hasil observasi awal yang di lakukan di dusun Karang Kates, Desa Mekar Sari Kecamatan Narmada Kabupaten Lombok Barat Provinsi Nusa Tenggara Barat, dimana sebagian besar masyarakat kurang memahami tentang penyakit rhematoid arthritis dan masyarakat sangat bergantung pada obat-obatan untuk menghilangkan nyeri yang di rasakan. Adapun terapi farmakologis atau obat-obatan yang di gunakan untuk mengurangi nyeri pada penyakit rhematoid arthritis adalah obat jenis non steroid dengan salah satu efek serius yang di akibatkan dari obat tersebut adalah perdarahan saluran cerna (Damanik, 2019).

Sebagai solusi atas permasalahan di atas maka di perlukan pemahaman dasar tentang rhematoid arthritis kepada masyarakat sebagai upaya pencegahan serta mengurangi frekuensi kekambuhan pada klien. Berbagai upaya dapat dilakukan untuk mengurangi nyeri baik secara farmakologi maupun non farmakologi. Manajemen nyeri secara farmakologi lebih efektif dibanding dengan metode non farmakologi namun metode farmakologi lebih mahal dan berpotensi mempunyai efek yang kurang baik, sehingga pemberian solusi terapi non farmakologis sebagai alternatif penanganan awal nyeri pada rhematoid arthritis merupkan pilihan yang tepat untuk mengurangi resiko terjadinya 
berbagai komplikasi sebagai akibat konsumsi obat anti inflamsi non steroid yang terlalu sering.

Selain dengan melakukan kegiatan penyuluhan sebagai upaya untuk meningkatkan pengetahuan masyarakat tentang penyakit rhematoid arthritis, berbagai jenis intervensi keperawatan dapat menjadi alternatif pilihan bagi masyarakat sebagai terapi non farmakologis untuk mengurangi intensitas nyeri pada klien rhematoid arthritis salah satunya dengan intervensi terapi yoga dengan kombinasi gerakan open kinetik chain exercise menggunakan music keroncong, serta mengajarkan terapi non farmakologis sebagai alternatif pengobatan untuk mengurangi intensitas gejala nyeri pada klien rhematoid arthritis.

\section{TUJUAN}

Pengabdian masyarakat di Dusun Karang Kates, Desa Mekar Sari Kecamatan Narmada Kabupaten Lombok Barat bertujuan agar masyarakat memiliki pengetahuan dasar tentang rhematoid arthritis, serta mampu menerapkan intervensi nonfarmakologis untuk mengurangi gejala nyeri berupa senam yoga kombinasi open kinetik chain exercise menggunakan music keroncong.

\section{METODE}

Adapun metode pelaksanaan kegiatan pengabdian ini adalah :

1. Pre Test

Pada tahap ini dilakukan pengkajian terhadap pengetahuan warga tentang penyakit rhematoid arthritis, pengkajian keluhan nyeri yang dirasakan dan pengukuran tekanan darah sebelum dilakukan penyuluhan kesehatan dan senam yoga kombinasi open kinetik chain exercise menggunakan music keroncong.

2. Pemaparan Materi

Pada tahap ini dilakukan pemaparan materi tentang rhematoid arthritis mulai dari pengertian, penyebab, tanda dan gejalanya, komplikasi dan penatalaksanaanya dengan metode ceramah dan diskusi menggunakan media LCD. Setelah pemaparan materi, selanjutnya dilakukan diskusi. Warga dipersilahkan untuk bertanya tentang hal-hal yang belum dipahami terkait materi penyuluhan.

3. Senam

Setelah pemaparan materi selanjutnya bersama-sama warga melakukan senam yoga kombinasi open kinetik chain exercise menggunakan music keroncong. Senam dilakukan sekitar 30 menit.

4. Post Test

Pada tahap ini dilakukan pengkajian kembali pengetahuan warga mengenai rhematoid arthritis setelah diberikan waktu istirahat selama 10 menit setelah senam yoga. Selanjutnya dilakukan pengkuran skala nyeri dan pengukuran tekanan darah post intervensi senam yoga.

5. Monitoring dan Evaluasi

Pada tahap ini tim pengabdian masyarakat melakukan evaluasi dan monitoring terhadap pelaksanaan senam yoga kombinasi open kinetik chain exercise menggunakan music keroncong yang rutin dilakukan 1x seminggu tiap hari Jumat di Balai Desa Mekar Sari. Monitoring kembali dilakukan 2 minggu setelah pelaksanaan pengabdian masyarakat. Saat monitoring, dilakukan pula pengkajian terhadap keluhan nyeri yang dirasakan warga sebagai evaluasi setelah menerapkan secara mandiri senam yoga kombinasi open kinetik chain exercise menggunakan music keroncong. 


\section{Journal of Community Engagement in Health}

http://jceh.org

ISSN: 2620-3758 (print); 2620-3766 (online)

https://doi.org/10.30994/jceh.v3i1.38

Vol.3 No.1. March 2020. Page.67-73

\section{HASIL}

Berikut hasil pengukuran pengetahuan warga tentang Rematoid Artritis, Tingkat Nyeri dan tekanan Darah sebelum dan sesudah kegiatan PKM pada warga di Dusun Karang Kates, Desa Mekar Sari Kecamatan Narmada, Lombok Barat.

Tabel 1 Distribusi Frekuensi Pengetahuan warga tentang rhematoid arthritis di Dusun Karang Kates, Desa Mekar Sari Kecamatan Narmada, Lombok Barat

\begin{tabular}{|c|c|c|c|}
\hline No & Pengetahuan Pretest & Frekuensi & Persentasi \\
\hline 1 & Kurang & 23 & $53,5 \%$ \\
\hline 2 & Cukup & 17 & $39,5 \%$ \\
\hline 3 & Baik & 3 & $7 \%$ \\
\hline & Total & 43 & $100 \%$ \\
\hline No & Pengetahuan Posttest & Frekuensi & Persentasi \\
\hline 1 & Kurang & 18 & $41,9 \%$ \\
\hline 2 & Cukup & 21 & $48,8 \%$ \\
\hline 3 & Baik & 4 & $9,3 \%$ \\
\hline & Total & 43 & $100 \%$ \\
\hline
\end{tabular}

Berdasarkan tabel 1 diatas terlihat sebagian besar tingkat pengetahuan warga tentang rhematoid arthritis sebelum diberikan penyuluhan yaitu kategori kurang sebanyak 23 orang $(53,5 \%)$ dan setelah diberikan penyuluhan sebagian besar terjadi peningkatan pengetahuan menjadi kategori Cukup sebanyak 21 orang $(48,8 \%)$.

Tabel 2 Distribusi Frekuensi Tekanan Darah warga sebelum dan sesudah dilakukan senam yoga di Dusun Karang Kates, Desa Mekar Sari kecamatan Narmada, Lombok Barat

\begin{tabular}{ccccc} 
No & Tekanan Darah Pre & Mean & Tekanan Darah Post & Mean \\
\hline 1 & Sistol & 140,2 & Sistol & 132,8 \\
\hline 2 & Diastol & 83,9 & Diastol & 81,8 \\
\hline
\end{tabular}

Dari tabel 2 diatas terlihat adanya penurunan tekanan darah baik sistol maupun diastol setelah dilakukan senam yoga kombinasi open kinetik chain exercise menggunakan music keroncong yaitu sistol pre 140,2 $\mathrm{mmHg}$ menjadi sistol post $132,8 \mathrm{mmHg}$ dan diastole pre $83,9 \mathrm{mmHg}$ menjadi diastole post $81,8 \mathrm{mmHg}$.

Tabel 3 Distribusi Frekuensi Nyeri rhematoid arthritis warga sebelum dan sesudah dilakukan senam yoga di Dusun Karang Kates, Desa Mekar Sari kecamatan Narmada, Lombok Barat

\begin{tabular}{ccccc}
\hline No & & Nyeri Pretest & Frekuensi & Persentasi \\
\hline 1 & Ringan & & 24 & $55,8 \%$ \\
\hline 2 & Sedang & & 19 & $44,2 \%$ \\
\hline 3 & Berat & & 0 & 0 \\
\hline & & Total & 43 & $100 \%$ \\
\hline No & & Nyeri Posttest & Frekuensi & Persentasi \\
\hline 1 & Ringan & & 28 & $65,1 \%$ \\
\hline 2 & Sedang & & 15 & $34,9 \%$ \\
\hline 3 & Berat & & 0 & 0 \\
\hline & & Total & 43 & $100 \%$ \\
\hline
\end{tabular}


Tabel 3 menunjukkan sebagian besar nyeri rhematoid arthritis yang dirasakan warga baik sebelum maupun sesudah dilakukan senam yoga kombinasi open kinetik chain exercise menggunakan music keroncong dalam kategori nyeri ringan sebanyak 24 orang $(55,8 \%)$ sebelum senam dan bertambah menjadi 28 orang $(65,1 \%)$ setelah senam. Hal ini menunjukkan adanya penurunan nyeri setelah dilakukan senam.

\section{PEMBAHASAN}

Kegiatan pengabdian kepada masyarakat ini dilakukan di rumah warga di Desa Mekar Sari yang dihadiri oleh 2 orang Kader, Kepala Desa, 43 orang warga dan 3 orang tim pengabdian. Dari hasil pengukuran tingkat pengetahuan warga tentang penyakit Rhematoid Arthritis didapatkan hasil adanya peningkatan pengetahuan warga setelah tim pengabdian memberikan penyuluhan tentang rhematoid arthritis. Dalam memberikan penyuluhan, tim menggunakan media LCD dengan tampilan gambar yang menarik sehingga mudah diingat oleh peserta. Organ yang paling banyak menyalurkan pengetahuan adalah mata. Lebih kurang $75-87 \%$ pengetahuan manusia diperoleh atau disalurkan melalui mata, dan 13-25\% lainnya tersalurkan melalui indera lain. Selain itu penyampaian materi juga menggunakan bahasa daerah setempat sehingga lebih mudah dimengerti oleh warga. Selain dengan pemaparan materi menggunakan LCD, media lain yang digunakan adalah leaflet yang diberikan kepada warga setelah pemaparan materi selesai.

Nyeri merupakan gejala utama pada pasien Rheumatoid Arthritis yang sering menyebabkan pasien membatasi aktivitasnya. Latihan penguatan dapat mengurangi keluhan nyeri. Kegiatan lain yang dilakukan dalam Pengmas ini adalah senam yoga kombinasi open kinetik chain exercise menggunakan music keroncong. Sebelum melakukan senam yoga kombinasi open kinetik chain exercise menggunakan music keroncong, harus dilakukan latihan pemanasan muskuloskletal dan kardiovaskular serta latihan fleksibilitas. Senam yoga dilakukan sebatas gerakan bebas nyeri serta harus menghindari postur dan gerakan yang meningkatkan nyeri.

Sebelum senam, peserta dilakukan pengukuran tekanan darah dan pengukuran skala nyeri yang selanjutnya dilakukan pengukuran kembali setelah senam. Dari hasil pengukuran tekanan darah dan skala nyeri rhematoid arthritis terjadi penurunan setelah dilakukan senam yoga kombinasi open kinetik chain exercise menggunakan music keroncong. Peserta terlihat antusias mengikuti semua kegiatan dan setiap gerakan senam mulai dari tahap pemanasan sampai akhir. Gerakan senam yang dipraktekkan juga sangat mudah diikuti dan tidak menyebabkan kelelahan pada peserta. Senam Yoga membuat tubuh lebih relaks sehingga dapat merangsang gelombang alfa pada otak yang terhubung dengan kondisi relaksasi yang mendalam dan kewaspadaan mental, hal ini dapat menurunkan tekanan darah. Latihan peregangan secara teratur dapat menguatkan otot jantung yang mengakibatkan jantung dapat memompa lebih banyak darah dengan usaha yang minimal. Sehingga, kerja jantung menjadi lebih ringan. Latihan peregangan juga dapat meningkatkan metabolisme lemak dengan penurunkan kadar LDL dan meningkatkan kadar HDL yang dapat mengakibatkan hambatan pada dinding arteri menjadi berkurang dan kekuatan aliran darah menjadi normal. Sehingga tekanan darah dapat menurun (Jain, 2011).

Teknik musik keroncong merupakan suatu teknik untuk mengkaji kekuatan pikiran saat sadar maupun tidak sadar untuk dapat menciptakan bayangan gambar yang membawa ketenangan dan keheningan (Widyastuti 2003, hlm 91). Mendengarkan musik yang memiliki tempo lambat seperti musik rohani dan musik tradisional akan menstimulasi pelepasan endorfin yang merupakan hormon anastetik alami (Avram Goldstein dari 
Addiction Research Center California dalam Campbell 2002,h. 87). Musik akan lebih efektif sebagai anastetik alami jika diberikan selama 15 menit pada klien (Potter\& Perry 2006, h. 1532).

Terapi senam yoga kombinasi kinetik chain exercise menggunakan music keroncong memiliki dampak psikologis langsung yakni membantu memberi perasaan santai, mengurangi ketengangan dan meningkatkan perasaan senang karena saat senam kelenjar pituari menambah produksi beta endorpin. Senam juga mempelanjar penyaluran saraf didalam otak yaitu meningkat neurotransmitter parasimpatis (norepinephrine, dopamine, dan serotinin). Teknik senam rematik juga menormalkan denyut jantung dan tekanan darah. Riset membuktikan bahwa teknik ini meningkatkan produksi beta endorfin yang dapat mengurangi rasa nyeri pada penderita rematik (Kuntaraf, 2010).

\section{KESIMPULAN}

Berdasarkan hasil pengabdian kepada masyarakat berupa penyuluhan kesehatan tentang rhematoid arthritis dan senam yoga kombinasi kinetik chain exercise menggunakan music keroncong yang dilakukan oleh tim maka dapat disimpulkan :

1. Adanya peningkatan pengetahuan tentang rhematoid arthritis pada warga desa Mekar Sari setelah diberikan penyuluhan.

2. Terjadi penurunan tekanan darah baik sistolik maupun diastolik setelah dilakukan senam yoga kombinasi open kinetik chain exercise menggunakan music keroncong.

3. Terjadi penurunan skala nyeri rhematoid arthritis setelah dilakukan senam yoga kombinasi open kinetik chain exercise menggunakan music keroncong

\section{REFERENSI}

Andriana, M. (2016). Pengaruh Kompres Serei Hangat Terhadap Penurunan Intensitas Nyeri Artritis Rheumatoid Pada Lanjut Usia. Sumbar: https://ejournal.kopertis10.or.id/index.php/jit/article/view/431-804/368.

Damanik, D. N. (2019). Pengaruh Kompres Hangat Terhadap Intensitas Nyeri Pada Lansia Yang Mengalami Reumatoid Artritis Di Desa Kotasan Kecamatan Galang. Medan: http://jurnal.stikes-aufa.ac.id/index.php/health/article/view/123.

Dewi, A. P \& Asnita, L. (2016). Buku Ajar Perawatan Lansia Penderita Nyeri Sendi Dalam Keluarga dan Masyarakat. Riau: Ur Press

Jain, Ritu. (2011). Pengobatan alternatif untuk mengatasi tekanan darah. Jakarta : Gramedia Pustaka Utama

Kumar, B \& Linert, P. (2016). Gout and African American reducing dispaties. Amerika: Clevaland Clinic Jurnl of Medicine.

Kemenkes RI. (2013). Profil Kesehatan Indonesia tahun 2013. Jakarta: Kementrian Kesehatan Republik Indonesia.

Kemenkes RI. (2019). Profil Kesehatan Indonesia tahun 2018. Jakarta: Kementrian Kesehataan Republik Indonesia.

Kuntaraf, J. 2010. Olahraga Sumber Kesehatan. Bandung : Advent Indonesia.

Lingga, L. (2012). Bebas penyakit asam urat tanpa obat. Jakarta: PT. Agro Media Pusaka. 
Perry,poter.2006. Fundamental keperawatan.EGC: Jakarta

World Health Organization (WHO). (2017). WHO methods and data sources global burden of diasese estimates 2000-2015.

Zeng, Q.Y et al (2008). Rheumatic diseases in China. Arthritis research \& therapy, 10(1), p.R17. 